\title{
Essay on Building Performance Management for Family Business Company based in Kuwait
}

\section{Payal Chadha*}

Swiss Management Center, University Zug, Kuwait

Ashraf \& Company Ltd. (Family Business), based in Kuwait, specializes "in the supply and service of equipment and solutions in 3 fields, namely Medical Systems, Photography and Imaging, and Information Technology" [1]. The Company is recognized as the market leader in traditional and digital medical and dental diagnostic imaging equipment and supplies, color films, color paper and information, document and workflow management systems [1]. The office headquarters has their logistic and warehouse facility within the building [1].

The basic goal for any business is to generate profits. To enhance the family business further, we recommend the following KPIs:

- Salary Competitiveness Ratio (SCR) - Competition for the best employee is severe in markets and an attractive salary package is equally significant to magnetize and retain employee's loyalty.

- Net Profit Margin - Indicates how efficient a company is at cost control. The higher the net profit margin, more effective the company is at converting revenue into actual profit [2].

- Order Fulfillment Cycle Time - It is the most vital and laborintensive process within the distribution center. As a cost center, order fulfillment and refill accounts for 50-65 percent of warehouse labor expense. Continuous enhancement of the order fulfillment process is important for better planning - in both manual and automated systems [3].

- Employee Satisfaction Index - Employees that are more contented lead to higher profits and is a good indication of future success [4].
- Average amount of products shipped to one customer - This indicator helps us track which products and customers are leading and which ones need improvement to generate more revenue.

Calandro [5] stated that the fraud metric, Altman's Z- score could be a good source for analyzing financial performance of an organization. The finance and account teams in Ashraf can use this model to see if the firm is in distress or not. The Z-score model has been a well-accepted financial distress model for almost four decades, and influential in areas such as credit risk analysis, merger and acquistion target analysis, and turnaround management. Since, Ashraf is a private firm, the Z-score modified formula is: $\mathrm{Z}=6.56 \mathrm{X} 1+3.26 \mathrm{X} 2+6.72 \mathrm{X} 3+1.05 \mathrm{X} 4$, where $\mathrm{X} 1=$ working capital/total assets; $\mathrm{X} 2=$ retained earnings/total assets; $\mathrm{X} 3=$ earnings before interest and taxes/total assets; and $\mathrm{X} 4=$ net worth/ total liabilities [5]. The criteria used to interpret the revised model are: Safe Zone $=\mathrm{Z}>2.60$; Distress Zone $=\mathrm{Z}<1.10$; and Grey Zone $=1: 10<=\mathrm{Z}$ $<=2.60$.

\section{References}

1. Ashraf \& Co (2005) Corporate Information.

2. http://www.investopedia.com/terms/n/net_margin.asp

3. http://www.werc.org/assets/1/publications/intelligrated_orderfulfillment_20111014.pdf

4. Becher J (2007) Measuring Employee Satisfaction.

5. Calandro $\mathrm{J}$ (2007) Considering the utility of Altman's Z-score as a strategic assessment and performance management tool. Strategy \& Leadership 35: $37-43$.
This article was originally published in a special issue, Collection of Finance Research handled by Editor. Payal Chadha, Swiss Management Center University Zug, Kuwait
*Corresponding author: Chadha P, Swiss Management Center, University Zug, Kuwait, Tel: +96569078096; E-mail: payal.chad@gmail.com

Received May 10, 2016; Accepted June 22, 2016; Published June 27, 2016

Citation: Chadha P (2016) Essay on Building Performance Management for Family Business Company based in Kuwait. Int J Account Res S1: 003. doi:10.4172/2472114X.S1-003

Copyright: @ 2016 Chadha P. This is an open-access article distributed under the terms of the Creative Commons Attribution License, which permits unrestricted use, distribution, and reproduction in any medium, provided the original author and source are credited. 